\title{
Antioxidant activity of Spathodea campanulata (Bignoneaceae) extracts
}

HEIM, S.C. ${ }^{1}$; GUARNIER, F.A. ${ }^{1}$; FERREIRA, D.T. ${ }^{2}$; BRAZ-FILHO, R. ${ }^{3}$; CECCHINI, R. ${ }^{~}$; CECCHINI, A.L. ${ }^{1 *}$

${ }^{1}$ Laboratório de Fisiopatologia dos Radicais Livres, Universidade Estadual de Londrina, CEP: 86051-990, LondrinaBrasil ${ }^{2}$ Laboratório de Pesquisas em Moléculas Bioativas, Departamento de Química, Universidade Estadual de Londrina, CEP: 86051-990, Londrina-Brasil ${ }^{3}$ Setor de Química de Produtos Naturais - LCQUI-CCT, Universidade Estadual do Norte Fluminense CEP: 28015-620, Campos-Brasil

\begin{abstract}
Spathodea campanulata is used in traditional medicine in Africa as diuretic and antiinflammatory. Although few studies have reported the mechanism of antioxidant action, this study evidenced the antioxidant activity of $S$. campanulata bark and flower extracts and their possible mechanism of action. Ethanol extracts of $S$. campanulata bark and flowers showed antioxidant activity on lipid peroxidation of liver microsome induced by $\mathrm{Fe}^{3+}$-ascorbic acid. Bark extract was 5 times more efficient than flower extract. The antioxidant activity of flower extract, previously complexed with increasing concentrations of $\mathrm{Fe}^{3+}(20-100 \mu \mathrm{M})$ which resulted in antioxidant activity loss, was shown to be related to iron complex formation. In contrast, the antioxidant activity of bark extract was not inhibited by the previous incubation with $\mathrm{Fe}^{3+}$, although complexation was demonstrated by spectral analysis of the solution. These results suggest an antioxidant mechanism other than $\mathrm{Fe}^{3+}$ complex formation. Therefore, the antioxidant mechanisms of $S$. campanulata flower and bark extracts are distinct from each other, reflecting the extract heterogeneous composition and the mechanism of action.
\end{abstract}

Key words: Spathodea campanulata, antioxidant, lipidperoxidation, bark extract, flower extract

RESUMO: Atividade antioxidante de extratos de Spathodea campanulata (Bignoneaceae). Spathodea campanulata é usada na medicina popular na África como diurético e antiinflamatório. Embora poucos estudos relatem o mecanismo de ação antioxidante, neste trabalho foi evidenciado a atividade antioxidante dos extratos da casca e da flor da S. campanulata e o possível mecanismo de ação. Os extratos etanólicos da casca e da flor da S. campanulata mostrou possuir atividade antioxidante sobre a lipoperoxidação de microssoma hepático induzida por $\mathrm{Fe}^{3+}$-ácido ascórbico. $\mathrm{O}$ extrato da casca foi 5 vezes mais eficiente que da flor. $\mathrm{O}$ extrato da flor foi previamente complexado com concentrações crescentes de $\mathrm{Fe}^{3+}(20-100 \mu \mathrm{M})$ o qual resultou na perda da atividade antioxidante, demonstrando que esta está relacionada com a formação de complexo com o ferro. Por outro lado, a atividade antioxidante do extrato da casca não foi inibida pela prévia incubação com o ferro, embora haja a formação do complexo evidenciado pela análise espectral da solução. Estes resultados sugerem que o mecanismo antioxidante seja outro que não a complexação com o $\mathrm{Fe}^{3+}$. Portanto, o mecanismo antioxidante dos extratos da flor e da casca da S. campanulata é distinto entre si o que reflete a composição heterogênica do extrato e o mecanismo de ação.

Palavras-chave: Spathodea campanulata, antioxidante, lipoperoxidação, extrato da casca, extrato da flor

\section{INTRODUCTION}

The species Spathodea campanulata $P$. Beauv. belongs to the family Bignoniaceae and is native to equatorial Africa. It is often used in gardening in tropical and subtropical areas, including South America (Joly, 1985). This species is largely used in traditional medicine; its flowers are used as diuretic and anti-inflammatory, while its leaves are used against kidney diseases, urethra inflammation and as antidote against animal venoms. Stem bark preparations are used against fungal skin diseases, herpes, stomachache and diarrhea (Mendes et al., 1986).

The widespread use of $S$. campanulata in

Recebido para publicação em 25/09/2010

Aceito para publicação em 28/09/2011

Rev. Bras. PI. Med., Botucatu, v.14, n.2, p.287-292, 2012. 
traditional medicine has stimulated more accurate pharmacological studies. Its flower and stem bark extracts have shown molluscicidal activity (Mendes et al., 1986). Hypoglycemic, anti-HIV and antimalarial activities were also observed for stem bark extracts (Makinde et al., 1988; Niyonzima et al., 1999). Shoots and two of the isolated fractions from celite column showed strong antioxidant activity (Nazif, 2007).

Phytochemical studies were performed with different parts of $S$. campanulata, including stem barks, leaves, flowers and fruits. Spathodic acid, steroids, saponins, ursolic acid, tomentosolic acid and pectic substances were isolated from the stem bark (Ngouela et al., 1990, 1988; Amusan et al., 1995, 1996; Niyonzima et al., 1999). The leaves contain spathodol, caffeic acid, other phenolic acids and flavonoids (Subramanian et al., 1973; Ngouela et al., 1991; El-Hela, 2001a; 2001b), while the fruits contain polyphenols, tannins, saponins and glucosides (Amusan et al., 1995). Banerjee \& De (1993) showed the presence of anthocyanins in flowers of $S$. campanulata, and Petacci et al. (1998) reported that the floral nectar contains a complex mixture of triterpenoids and steroids. The initial study of $S$. campanulata root peels by our group identified an iridoid glucoside (ajugol) and two phenolic derivatives ( $p$-hydroxy-benzoic acid and methyl $p$-hydroxybenzoate). Bioactivities of the compounds were evaluated against the fungus Cladosporium herbarum (Pianaro et al., 2007).

There are few studies about the antioxidant effect of S. campanulata (Houghton et al., 2005) which offer only a borderline approach. The extracts reduced the peroxidation of bovine brain extract and protected MRC- 5 cells from hydrogen peroxide-induced oxidant injury (Mensah et al., 2006). In the present study, the possible metal chelating and/or complexation effects of Spathodea campanulata flower and bark ethanol extracts were investigated for their possible antioxidant mechanisms.

\section{MATERIAL AND METHOD}

\section{Plant materials}

A specimen of Spathodea campanulata root, family Bignoniaceae, was harvested from the campus of Londrina State University (UEL), Paraná State, Brazil. S. campanulata (6 years old, flowering) specimens were harvested during the summer. A voucher specimen was deposited at the Herbarium of UEL for botanical specification.

\section{Hepatic microsomal lipoperoxidation inhibition by Spathodea campanulata}

Hepatic microsomes were obtained and lipid peroxidation inhibition was performed (Cecchini et al.,
1990). The reaction mixture contained the following reagents at the final concentrations from 0.5 to 0.9 $\mathrm{mg} \mathrm{mL}^{-1}$ protein microsomes, $20 \mathrm{mM} \mathrm{KH}_{2} \mathrm{PO}_{4} \mathrm{pH}$ 7.4, $100 \mathrm{mM} \mathrm{FeCl}_{3}$, and $100 \mu \mathrm{M}$ ascorbic acid. Ethanol extracts at increasing concentrations up to $3 \mathrm{mg} \mathrm{mL}^{-1}$ of both roots and flowers dissolved in $80 \%$ ethanol, $20 \mathrm{mM} \mathrm{KH_{2 }} \mathrm{PO}_{4}-\mathrm{KOH}, \mathrm{pH} 7.4$, were used in the incubation medium.

To verify the formation of a complex between the extracts and $\mathrm{Fe}^{3+}$, about $1.53 \mathrm{mg} \mathrm{mL}^{-1}$ root extract and $1.56 \mathrm{mg} \mathrm{mL}^{-1}$ flower extract were previously incubated with 10 to $100 \mathrm{mM} \mathrm{FeCl}_{3}$. The reaction mixtures were incubated in metabolic stirrer Dubnoff at $37^{\circ} \mathrm{C}$ for $15 \mathrm{~min}$. Following incubation, peroxidation was measured by the TBA test (Cecchini et al., 1990).

\section{Spectrophotometric $\mathrm{Fe}^{3+}$-Spathodea campanulata complex formation}

The root extract was diluted in $80 \%$ ethanol to a final concentration of $30 \mathrm{mg} \mathrm{mL}^{-1}$ and added to $40,80,120$ and $160 \mu \mathrm{M} \mathrm{FeCl}_{3}$ (final concentration) followed by spectral analysis from 350 to $450 \mathrm{~nm}$ in a spectrophotometer Varian model $634 \mathrm{~S}$.

\section{Statistical analysis}

Data were evaluated using an unpaired Student's $t$ test.

\section{RESULT}

\section{Microsomal lipid peroxidation}

Both the bark and the flower extract significantly inhibited lipid peroxidation induced by $\mathrm{Fe}^{3+}$ - ascorbic acid. The bark extract showed a pronounced inhibitory effect, reaching approximately $95 \%$ at $1.5 \mathrm{mg} \mathrm{mL}^{-1}$, while the flower extract inhibition reached no higher than $35 \%$ at $3 \mathrm{mg} \mathrm{mL}^{-1}$. At $1.5 \mathrm{mg}$ $\mathrm{mL}^{-1}$, the bark extract showed 5 times more antioxidant activity than the flower extract. In addition, both extracts revealed a biphasic profile with a fast increase at the beginning, followed by a slower phase (Figure $1 \mathrm{~A})$. The time course of lipid peroxidation inhibition revealed a prompt reaction between the system $\mathrm{Fe}^{3+}$ ascorbic-acid-microsome and the substances present in both extracts. Maximal inhibition occurred at $1 \mathrm{~min}$ followed by steady-state behavior (Figure 1B).

Inhibition of $\mathrm{Fe}^{3+}$-ascorbic acid-induced
lipid peroxidation by complex formation
The possible complex formation of $\mathrm{Fe}^{3+}$ with
substances present in the extracts was investigated
as a mechanism of lipid peroxidation inhibition. To
achieve this, different concentrations of $\mathrm{FeCl}_{3}$ were
previously incubated with the bark or the flower extract
and TBA test was performed. As shown in Figure 2 ,
lipid peroxidation was still inhibited by the bark extract



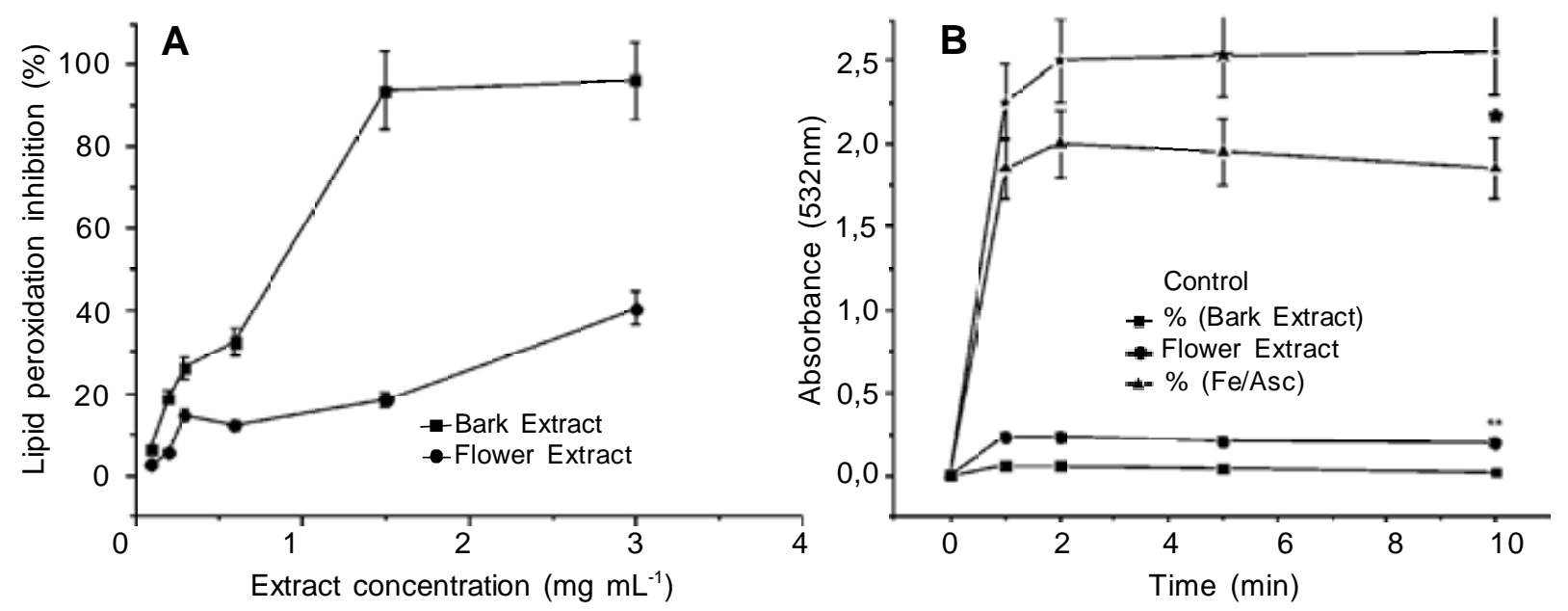

FIGURE 1. (A) Lipid peroxidation inhibition by bark and flower extracts at increasing concentrations. Microsomal lipid peroxidation was stimulated by ascorbic acid - $\mathrm{Fe}^{3+}$, as described in Material and Method. (B) Time course of lipid peroxidation inhibition by $1.64 \mathrm{mg} \mathrm{mL}^{-1}$ bark and $1.56 \mathrm{mg} \mathrm{mL}^{-1}$ flower extract. The inhibition of lipid peroxidation induced by Fe/ascorbic acid remained up to 10 min incubation. ${ }^{*} p<0.05^{* *} p<0.001$ when compared to microsomes alone during Fe/Asc-stimulated lipid peroxidation.

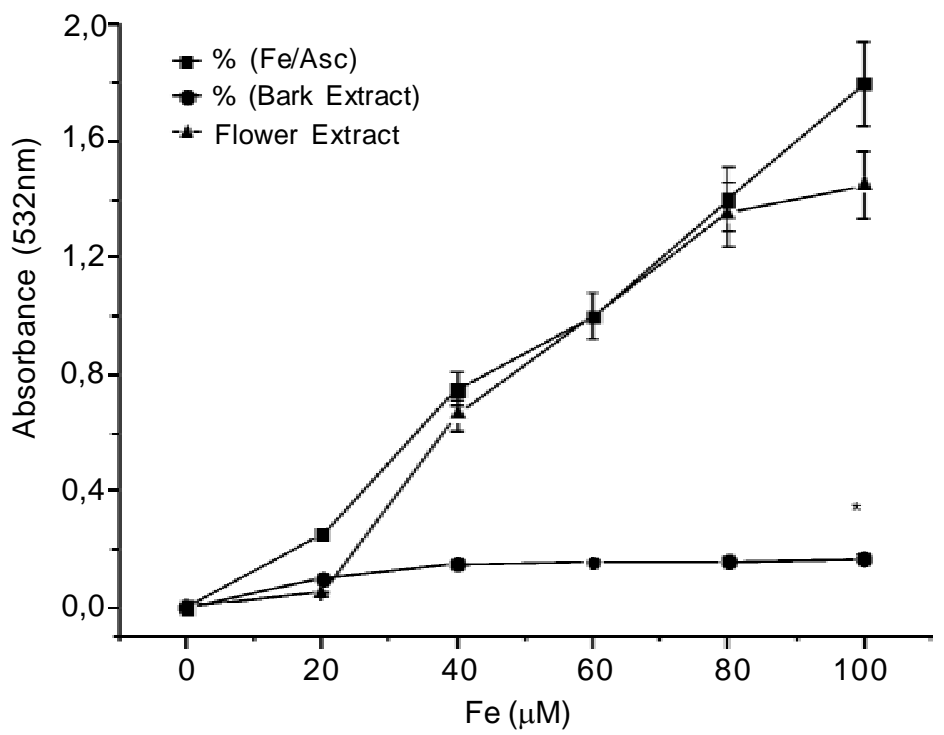

FIGURE 2. Effect of increasing concentrations of $\mathrm{Fe}^{3+}$ on the lipid peroxidation inhibition activity of bark and flower extracts. Different concentrations of $\mathrm{Fe}^{3+}$ were previously incubated with $1.64 \mathrm{mg} \mathrm{mL}^{-1}$ bark or $1.56 \mathrm{mg} \mathrm{mL}^{-1}$ flower extract. ${ }^{*} p<0.001$.

but not by the flower extract, indicating that $\mathrm{Fe}^{3+}$ made a stable complex with the flower extract which interfered with its antioxidant activity.

\section{Complex formation between the bark extract and $\mathrm{Fe}^{3+}$}

The addition of $\mathrm{FeCl}_{3}$ to bark extract resulted in increased absorbance at $378 \mathrm{~nm}$. This curve is revealed in Figure 3 by the differential spectra. The intensity increased at $160 \mu \mathrm{M} \mathrm{Fe}{ }^{3+}$. Above this concentration, distortion of the band occurs (data not shown).

\section{DISCUSSION}

Various species of Bignoneaceae family have been investigated regarding their phytochemical activities due to the phenolic compounds among flavonoids (for review, see Andrade-Cetto et al., 2005). Flavonoids have been shown to inhibit lipid peroxidation and to protect tissue from the damage caused by oxygen reactive species (Laughton et al., 1989; Afanas'Ev et al., 1989), and phenolic compounds usually work as inhibitors of the lipid peroxidation chain reaction (Charami et al., 2008). 


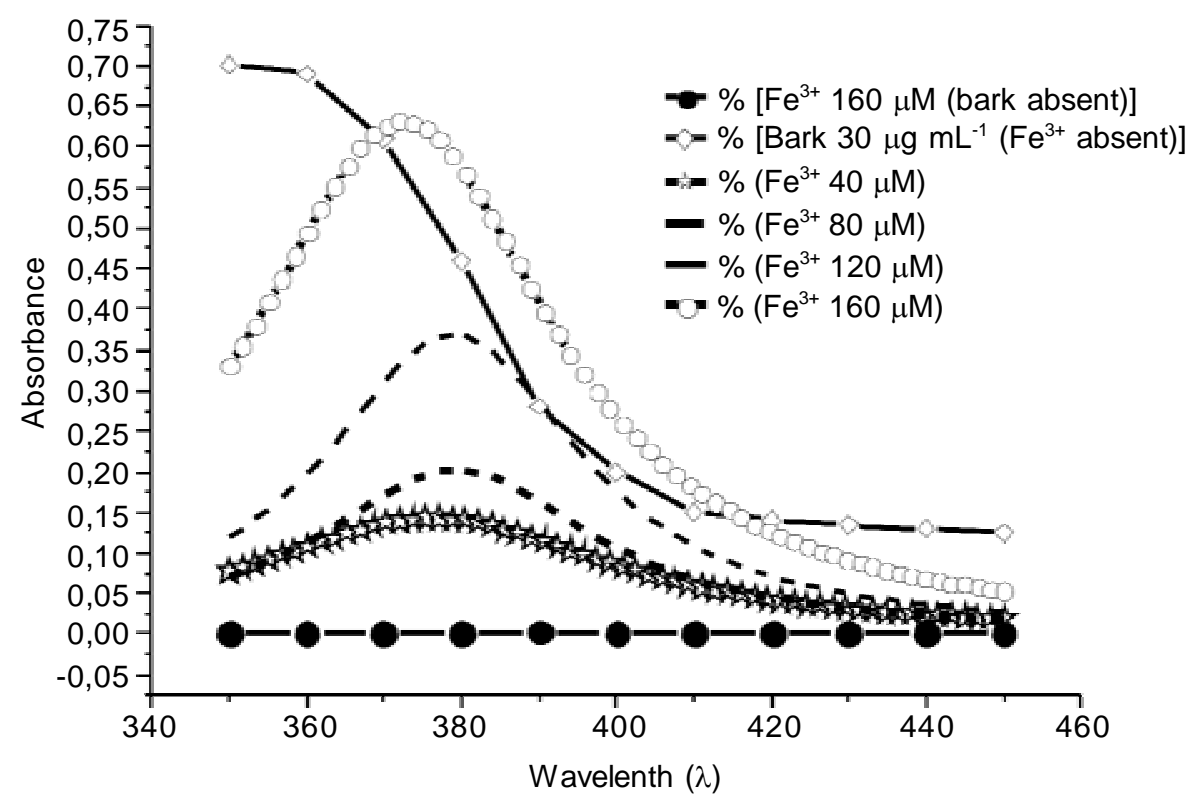

FIGURE 3. Absorption spectra of bark extract previously complexed with different concentrations of $\mathrm{Fe}^{3+}$.

A large number of studies have been conducted in order to evaluate the antioxidant capacity of phenolic compounds (Kook et al., 2008; Koleckar et al., 2008), though few discuss possible mechanisms of their antioxidant activity. In this study, the antioxidant activity of Spathodea campanulata bark and flower extracts were verified and one of the possible biological mechanisms of action was identified.

Lipid peroxidation of rat liver microsomes induced by $\mathrm{Fe}^{3+}$ and ascorbic acid was inhibited by both bark and flower extracts (Figure 1). When $\mathrm{Fe}^{3+}$ and ascorbic acid are added to hepatic microsomes, a rapid lipid peroxidation occurs, which is markedly reduced by the bark extract, but only mildly diminished by the flower extract. Inhibition was dose-dependent and it is possible that the identified phenolic compounds (Figure 4) were responsible for this activity. Although the chain break reaction has been postulated as the main mechanism by which phenolic compounds and plant extracts inhibit lipid peroxidation (Charami et al., 2008), the results obtained in this study indicate another major mechanism involved in this process, the ascorbic acid - $\mathrm{Fe}^{3+}$ mechanism, which induces biological membrane lipid peroxidation.

$\mathrm{Fe}^{3+}+$ ascorbic acid $\longrightarrow \mathrm{Fe}^{2+}+$ ascorbic acid ox $\mathrm{Fe}^{2+}+\mathrm{H}_{2} \mathrm{O}_{2} \longrightarrow \mathrm{Fe}^{3+}+\mathrm{O}_{2}+{ }^{-} \mathrm{OH}+{ }^{\cdot} \mathrm{OH}$ $\cdot \mathrm{OH}+$ lipid $\longrightarrow$ lipid peroxidation

To understand the role of $\mathrm{Fe}^{3+}$ in the extract complex formation that participates in the reduction of lipid peroxidation, increasing concentrations of $\mathrm{Fe}^{3+}$ were previously incubated with flower and bark extracts, after which the assay was performed. The antioxidant activity of the flower extract was abolished, demonstrating that the complex formation between the extract and $\mathrm{Fe}^{3+}$ is the main antioxidant mechanism. In contrast, the antioxidant activity of the bark extract remained, independent of preincubation with increasing concentrations of $\mathrm{Fe}^{3+}$. Complex formation between both flower and bark extracts and $\mathrm{Fe}^{3+}$ was confirmed by spectral analysis. Analysis of the mixture of bark extract and $\mathrm{FeCl}_{3}$ (Figure 3 ) showed a change in the absorption spectrum, with a new absorption band at $378 \mathrm{~nm}$. The occurrence of this absorption band was dependent on the increasing concentrations of $\mathrm{Fe}^{3+}$ in the medium. This finding indicates the formation of a complex between the compounds of the bark extract and $\mathrm{Fe}^{3+}$. Complex preincubation did not show saturation up to $\mathrm{Fe}^{3+} 160$ $\mu \mathrm{M}$, suggesting multiple sites of interaction that do not interfere with its antioxidant activity. The flower extract showed the same spectra profile; however, the antioxidant activity was abolished (data not shown).

A large number of compounds isolated from the bark or the flower extract (Figure 4), such as ursolic acid (D'Abrosca et al., 2005) and phenylethanoid glycosides (Tath et al., 2007), have shown antioxidant activity (Tath et al., 2007). Antioxidant capacity in pure flavonoids: flavanomarein (isookanin 7-O-glucoside), cynaroside (luteolin 7-O-glucoside) and luteolin, was identified in Bur-marigold extracts (Wolniak et al., 2007). Complexation with iron was verified in a purified system, with D-glucopyranose (Hamai, 2001) and hydroxypyridone compounds (Merkofer et al., 2006). The present study used a more complex biological system and demonstrated that flower and bark extracts present antioxidant activity against a microsome $\mathrm{Fe}^{3+}$ / 


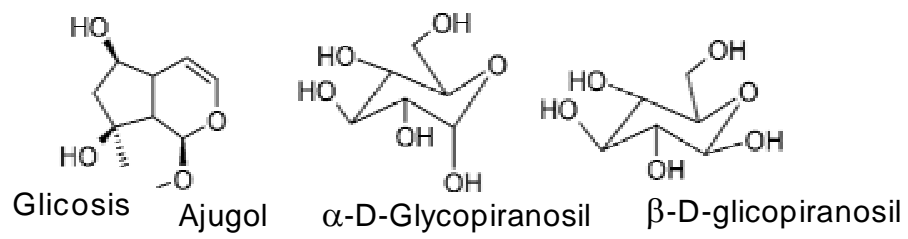<smiles>O=C(O)c1ccc(O)cc1</smiles>

$\rho$-hydroxybenzoic acid<smiles>COC(=O)c1ccc(O)cc1</smiles>

$\rho$-hydroxy-methylbenzoate

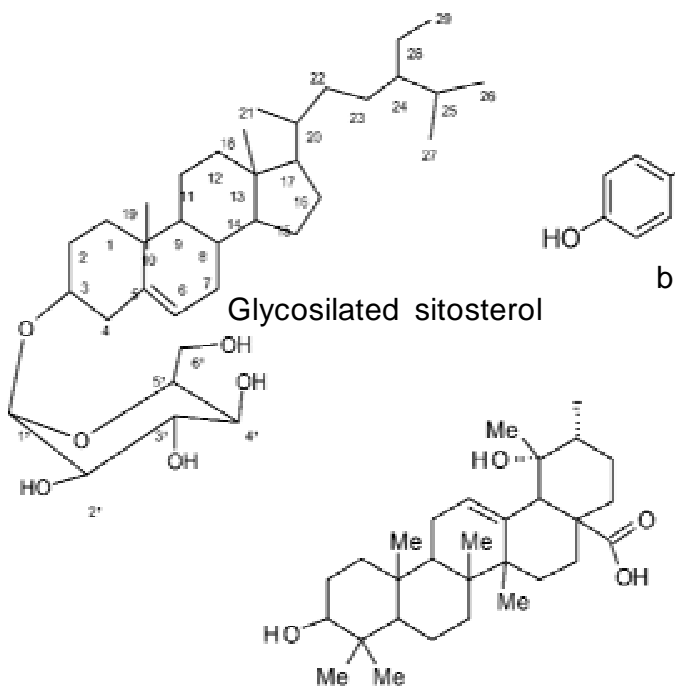

19- $\alpha$-hydroxy ursolic acid

FIGURE 4. Compounds identified in S. campanulata bark and flower extracts.

ascorbic acid lipid peroxidation-induced system (Figure 1). The mechanism by which this inhibition occurs is related to the capacity of flower extract to form a stable complex with $\mathrm{Fe}^{3+}$, abolishing thus the antioxidant activity. The complexation of bark extract with $\mathrm{Fe}^{3+}$ did not inhibit the antioxidant activity. These data suggest the existence of two distinct mechanisms of antioxidant action, an iron-dependent mechanism in the flower extract and an ironindependent mechanism in the bark extract.

In conclusion, the obtained data revealed that Spathodea campanulata flower and bark extracts present significant antioxidant capacity within a biological system in the presence of $\mathrm{Fe}^{3+}$ ascorbic acid. The bark extract showed 5 times more antioxidant activity than the flower extract. The latter revealed an iron-dependent antioxidant mechanism, while the bark extract presented an iron-independent antioxidant mechanism.

\section{REFERENCE}

AFANAS, E.V. et al. Chelating and free radical scavenging mechanisms of inhibitory action of rutin and quercetin in lipid peroxidation. Biochememical Pharmacology, v.38, n.11, p.1763-9, 1989.

AMUSAN, O.O.G.; ADESOGAN, E.K.; MAKINDE, J.M. Antimalarial active principles of Spathodea campanulata stem bark. Phytotherapy Research, v.10, p.692-3, 1996. AMUSAN, O.O.G.; MSONTHI, J.D.; MAKHUBU, L.P. Molluscicidal activity of Spathodea campanulata, Andrachne ovalis, Phytolacca dodecandra and Hypoxis rooperi. Fitoterapia, v.66, p.113-6, 1995.

ANDRADE-CETTO, A.; WIEDENFELD, H. Hypoglycemic effect of Acosmium panamense bark on streptozotocin diabetic rats. Journal of Ethnopharmacology, v.90, p.21720, 2004.

BANERJEE, A.; DE, B. Anthocyanins in some flowers of West Bengal. Journal of Medicinal and Aromatic Plant Science, v.23, p.600-4, 1993.

CECCHINI, R.; ARUOMA, O.I.; HALLIWELI, B. The action of hydrogen peroxide on the formation of thiobarbituric acid reactive material drom microsomes, liposomes or 
from DNA damaged by blomycin or phenanthroline. Artefacts in the thiobarbituric acid test. Free Radical Research Communication, v.10, n.4/5, p.245-58, 1990. CHARAMI, M.T. et al. Antioxidant and antiinflammatory activities of Sideritis perfoliata subsp. perfoliata (Lamiaceae). Phytotherapy Research, v.22, n.4, p.4504, 2008.

D'ABROSCA, B. et al. Radical scavenging activities of new hydroxylated ursane triterpenes from cv. Annurca apples. Chemistry \& Biodiversity, v.2, n.7, p.953-8, 2005. DAVIDSON, P.M.; BRANEN, A.L. Antimicrobials in foods. 3.ed., New York: Marcel Dekker, 1993. 263p.

El-HELA, A.A. Phenolics from Spathodea campanulata Beauv. leaves. Al-Azhar Journal of Pharmaceutical Sciences, v.27, p.152-62, 2001a.

EI-HELA, A.A. A new iridoid glucoside from Spathodea campanulata Beauv. leaves. Al-Azhar Journal of Pharmaceutical Sciences, v.27, p.115-20, $2001 \mathrm{~b}$.

HAMAI, S. Molecular recognition of malto-oligosaccharides by free and metal tetrakis(4-sulfonatophenyl) porphyrins in basic aqueous solutions. Journal of Nanoscience and Nanotechnology, v.1, n.2, p.177-84, 2001.

HOUGHTON, P.J. et al. In vitro tests and ethnopharmacological investigations: wound healing as an example. Journal of Ethnoparmacology, v.22, p.1007, 2005.

JOLY, A.B. Botânica. 7.ed. São Paulo: Editora Nacional, 1985. 723p.

KOLECKAR, V. et al. Evaluation of natural antioxidants of Leuzea carthamoides as a result of a screening study of 88 plant extracts from the European Asteraceae and Cichoriaceae. Journal of Enzyme Inhibition and Medicinal Chemistry, v.23, n.2, p.21824, 2008.

KOOK, D. et al. The protective effect of quercetin against oxidative stress in the human RPE in vitro. Investigative Ophthalmology \& Visual Science, v.49, n.4, p.1712-20, 2008.

LAUGHTON, M.J. et al. Antioxidant and prooxidant actions of plant phenolics quercetin, gossypol and myricetin. Effects on lipid peroxidation, hydroxyl radical generation and bleomycin dependant DNA damage. Biochemical Pharmacology, v.38, p.2859-65, 1989.

MAKINDE, J. M.; AMUSAN, O.O.G.;ADESOGAN, E.K. The antimalarial activity of Spathodea campanulata stem bark extract on Plasmodium berghei berghei in mice. Planta
Medica, v.54, p.122-5, 1988.

MENDES, N.M. et al. Atividade moluscicida de alguns produtos naturais sobre Biomphalaria glabrata. Memórias do Instituto Oswaldo Cruz, v.81, p.87-91, 1986. MENSAH, A.Y. et al. In vitro evaluation of effects of two Ghanaian plants relevant to wound healing. Phytotherapy Research, v.20, p.941-4, 2006.

MERKOFER, M. et al. Fenton chemistry and iron chelation under physiologically relevant conditions: electrochemistry and kinetics. Chemical Research in Toxicology, v.19, n.10, p.1263-9, 2006.

NAZIF, N.M. Phytochemical and antioxidant activity of Spathodea campanulata P. Beauvois growing in Egypt. Natural Product Sciences, v.13, n.1, p.11-6, 2007.

NGOUELA, S. et al. Spathodic acid: a triterpene acid from the stem bark of Spathodea campanulata. Phytochemistry, v.29, p.3959-61, 1990.

NGOUELA, S.; TSAMO, E.; SONDENGAM, B.L. Extractives from Bignoniaceae: constituents of the stem bark of Spathodea campanulata. Planta Medica, v.54, p.476, 1988.

NGOUELA, S. et al. Spathodol, a new polyhydroxysterol from the leaves of Spathodea campanulata. Journal of Natural Products, v.54, p.873-6, 1991.

NIYONZIMA, G. et al. Hypoglycemic, anticomplement and anti-HIV activities of Spathodea campanulata stem bark. Phytomedicine, v.6, p.45-9, 1999.

PETACCI, F. Novos componentes químicos para Spathodea campanulata (Beauv.), Bignoniaceae. In: REUNIÃO ANUAL DA SOCIEDADE BRASILEIRA DE QUÍMICA, 5., 1998, Poços de Caldas. Resumo... Poços de Caldas: SBQ, 1998. p.25.

PIANARO, A. et al. Iridoid glucoside and antifungal phenolic compounds from spathodea campanulata roots. Semina, v.28, p.251-6, 2007.

SUBRAMANIAN, S.S.; SULOCHANA, N.; NAGARAJAN, S. Caffeic acid from the leaves of Spathodea campanulata. Current Science, v.42, p.403, 1973.

TATH, I.I.; SCHUHLY, W.; AKDEMIR, Z.S. Secondary metabolites from bioactive methanolic extract of Verbascum pycnostachyum Boiss. \& Helder flowers. Hacettepe Universitesi Eczacilik Fakultesi Dergisi, v.27, n.1, p.23-32, 2007

WOLNIAK, M. et al. Antioxidant activity of extracts and flavonoids from Bidens tripartite. Acta Poloniae Pharmaceutica, v.64, n.5, p.441-7, 2007. 